\title{
THE Role OF SyNTACTIC STYLISTIC MEANS IN EXPRESSING THE EMOTION TERM LOVE
}

\author{
Nataliya Panasenko \\ cindy777@mail.ru \\ University of SS Cyril and Methodius in Trnava
}

\begin{abstract}
Love as one of important feelings in human emotional, cognitive and social life has always attracted attention of the researchers: psychologists, linguists, philosophers, ethnologists, etc. We may speak about extralinguistic and linguistic ways of love manifestation. To linguistic ones belong, of course, stylistic means, which include lexical, syntactic, phonetic, and semasiological level. The author focuses on lexical-syntactical means of expressing love in two Slavic languages, Czech and Slovak, using linguocognitive and cultural approach. This research is inspired by the GRID project, which aimed at study of 24 emotion terms in 35 languages.
\end{abstract}

Keywords: emotion term LOVE, linguistic and extralinguistic means of love manifestation, expressive syntax, fiction.

\section{Introduction}

There are different approaches to love as an emotion term, which have already been described in details by scholars representing different languages and cultures (Components of Emotional Meaning 2013). In this article I want to focus on linguistic means of expressing love in prosaic texts, namely means of expressive syntax, which itself has not been investigated yet, especially in connection with different cultures. I guess that people of different nationalities, even speaking languages of the same group, Slavic in our case, express their feelings in different ways. As far as we are going to discuss love, my hypothesis is that these scripts depend on many factors: (1) types of love (happy/shared vs. unhappy/unshared, romantic, tragic, common, homosexual, adultery, etc.; (2) number of participants (happy love - only two people + children in future; unhappy love - ménage à trois; adultery - three or more people); (3) other feelings and emotions which accompany love according to its type and participants; (4) stages of love (acquaintance, courting, dating, temporal separation, meetings, wedding or separation) and some others.

Another important aspect is love manifestation, with the help of extralinguistic (facial and vocal expression, bodily movements, shedding tears, smiling, laughing, giving gifts, etc.) and linguistic means (phonetic, lexical, morphological, syntactic and others) (Panasenko 2009). Let us consider the psycholinguistic approach to love. 


\section{Emotions and feelings from psycholinguistic point of view}

Psychologists and linguists have a common object of investigation: feelings and emotions, but approaches to its study may be different (Frijda 1986; Nakonečný 2000; Ortoni et al. 1988; Panasenko, Démuthová et al. 2012; Rozhkova 1974). Psychologists take into account different features accompanying emotions, such as features describing the person's evaluation or appraisal of the event, features describing the bodily symptoms that tend to occur during the emotional state (felt shivers in the neck or chest, got pale, felt his/her heartbeat slowing down, felt his/her heartbeat getting faster, felt his/her breathing getting faster, perspired, or had moist hands); features describing facial and vocal expressions, that accompany the emotion (blushed, smiled, felt his/her jaw drop, pressed his/her lips together, felt his/her eyebrows go up, frowned, closed his/her eyes, had tears in his/her eyes; changes in the loudness of voice, of speech melody, speech tempo, speech disturbances, etc.). All these symptoms are included into GRID project (Components of Emotional Meaning 2013), results of which I partially use in my research. These extralinguistic means, which have universal character, include bodily symptoms, facial and vocal expression, and some others (see figure 1).

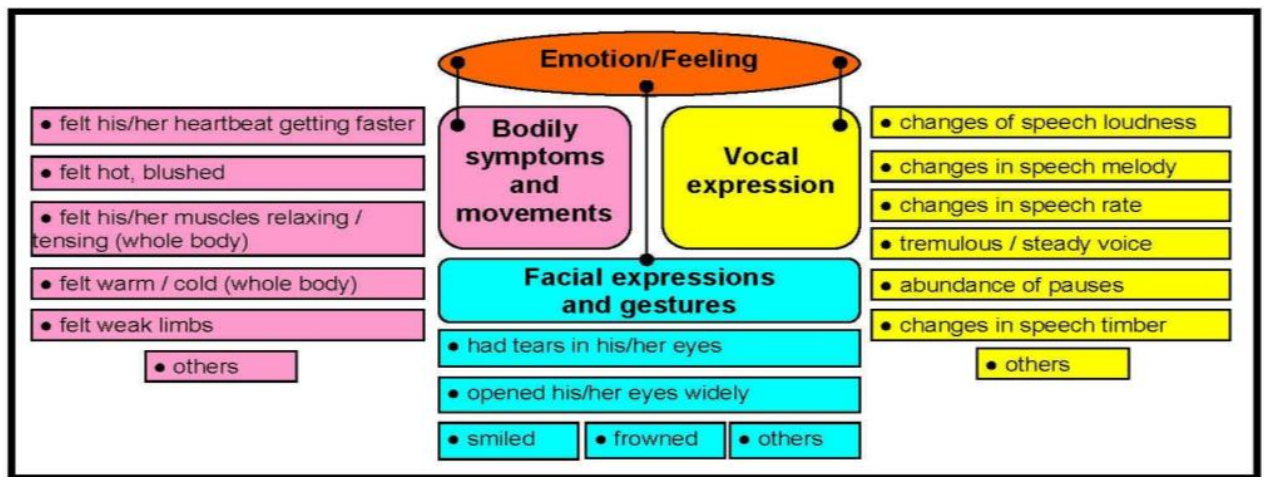

Figure 1: Extralinguistic means of expressing feelings and emotions in any language

Among all the linguistic ways of emotions/feeling manifestation I give the priority to syntax, because its role has been obviously underestimated and the number of its studies is limited (Kiseluik 2007; Panasenko 2012). Sometimes the study of grammatical means in expressing emotions and feelings is combined with the intonational (Panasenko, Krivonoska 1983) and lexical ones (Likharieva 1982).

We have done thorough analysis of linguistic and extralinguistic means (Panasenko, Trnka et al. 2013), which express love and hatred, but here I will concentrate on syntactic means of expressing emotional term LOVE. 


\section{Language material; emotion term LOVE in literary texts}

As a language material I have chosen works by modern Czech and Slovak authors (17 novels), mainly bestsellers translated into many languages. Using the method of complete selection I have found numerous examples in the texts connected with emotion term LOVE: different stages of relations, different types of love in combination with other emotions and feelings, different types of speech - the first person narrative, the author's description, meditation, inner monologue, dialogue, etc. The analysis of these texts shows that description of this or that emotional manifestation is very often being dispersed on several pages. In these texts I have come across different types of love, but now I will only highlight love between a man and a woman taking into account such positive and negative aspects as: declaration of love; happy, shared love; disillusionment in love; non-shared, unhappy love, and some others.

Traditionally shared love is defined as a complex feeling including such feelings as sympathy, tenderness, liking, etc. in combinations with such emotions as joy, happiness, admiration, passion, delight, etc. But there is also unhappy, non-shared love. In connection with this, I would like to mention a very interesting research conducted by Nikonova (2008) who analyzed concept LOVE in tragedies by William Shakespeare and presented it in the form of a frame (Figure 2), some parts of which I use in my research.

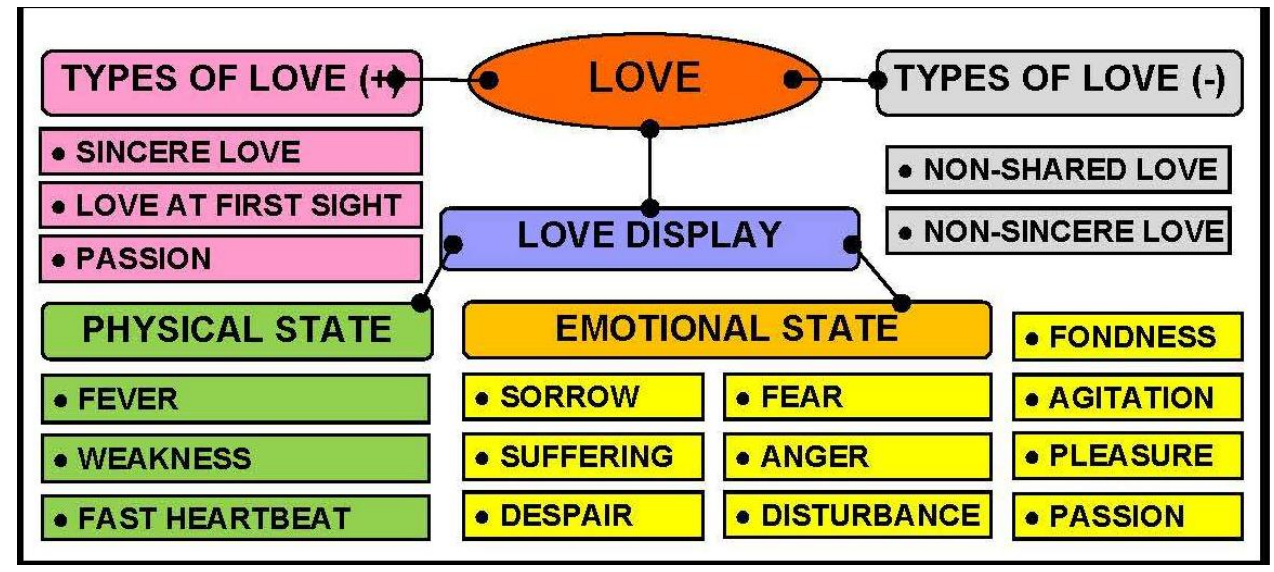

Figure 2: Frame of subject-sensual layer of literary concept LOVE (a fragment) (after Nikonova 2008)

A question arises: what makes love unhappy? As far as prose texts are concerned, we will find an answer to this question a bit later, but much depends on the genre of a story. In modern fiction, we may single out several types of love development with different number of people involved into it (Panasenko 2012). We'll start with common love which can be shared and non-shared. Let us reconstruct its stages in the way they are reflected in fiction with accompanying them emotions and present in the form of a scenario (see Figure 3). 


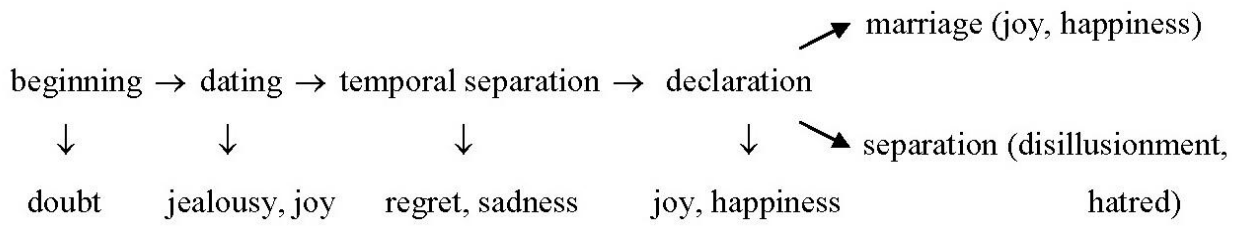

Figure 3: Scenario of love stages

The paradox is that in life everybody dreams of happy love, but in fiction it is not the main line of plot development. Some heroes are mentioned as the example of an ideal family: they love each other, have many children, enjoy love, but the reader waits for collisions, tragedies, tears, scandals - this is the main line of the plot structure for protagonists. If it is a novel, there are many characters in it and sometimes the reader must be very attentive to understand relations between all of them. Thus - two people happy love; the symbol for this will be an oval, which may be treated as an egg, that is symbol of future life and development (see Figure 4).

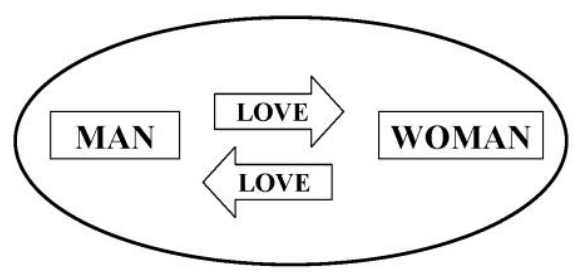

Figure 4: Oval - a model of happy love with two people involved

Happy love used to be associated with family relations. Our research (Panasenko 2013) shows that in the course of time Czech and Slovak family patterns and family values are changing; factors which made love happy/unhappy some time ago and nowadays do not coincide. If love is non-shared, there may be a rival - a man or a woman: a woman loves a man, but he loves another woman or a man; variety - adultery - a man is married and has a mistress whom he promises to marry in future; mistress definitely hates her rival; classical ménage à trois. Its symbol is a triangle (see Figure 5).

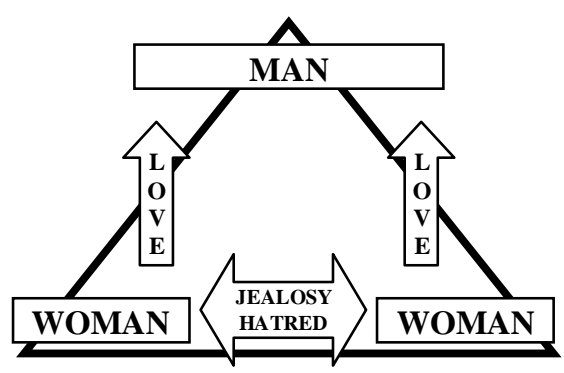

Figure 5: Triangle - a model of unhappy love with three people involved 
These relations may have a variety: a wife in revenge may find a lover, thus four people are involved. It's symbol is a square (Figure 6). As far as feelings of a man are described in different books in a different way here and above we omit them.

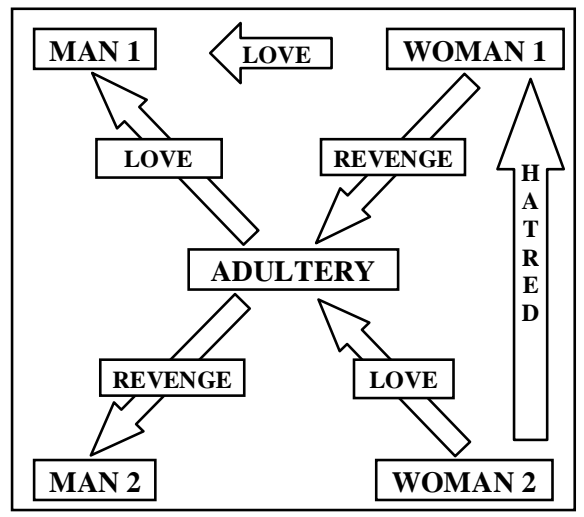

Figure 6: Square - a model of unhappy love with four people involved

\section{Manifestation of love in Czech fiction}

Czech examples form several groups with accompanying emotions, representing all three models mentioned above. I will present some samples. Let's start with happy love, the model of which is an oval. Here and below some comments are added to make the situation in the text clearer.

temporal separation: love + loneliness + regret

The girl felt great loneliness seeing off her boyfriend Honza and asked him to come back as soon as possible:

(1) Najednou jsem se cítila strašně opuštěná, chtěla jsem mu říct ještě tisíc věcí. Bez naděje jsem se podívala nahoru k oknům vlaku, Honza se nikdy nevykláněl, ale zrovna dneska tam byl. "Přijed' brzo!" zaknikala jsem žalostně (Hercíková "Jízda šikmo svahem", p. 141). (Czech)

Being alone, I felt horribly alone; I wanted to tell him a thousand more things. Without any hope I looked up at the train window, Honza never leaned out, but exactly today was there. "Come quick!" whimpered I in a plaintive voice.

meeting: love + joy

(2) Feeling of joy:

Pocit radosti ze setkáni tentokrát nedokázal prekonat všechny obtižze, kteté jsme mu házeli do cesty (Hercíková "Jízda šikmo svahem", p. 143-144). (Czech)

Feeling of joy from meeting this time didn't overcome all the hardships which he faced during his trip.

Model triangle: feelings of Anděla towards her lover's wife (Sharon) are described in the following way:

love + jealousy

(3) Direct mentioning of desire to kill her rival: 
Necitila jsem k Sharon zášt, snad nechut'. Ale zabit bych se mohla, aby byl pokoj, a zabila bych se, kdybych méla revolver. Prostřelit si hlavu mi pripadalo jako ucházejici smrt. (Hercíková "Vášeň", p. 181). (Czech)

I didnt feel hatred for Sharon, perhaps reluctance. But I could kill, to keep peace, and I would have killed her, if I had a revolver. To shoot through my head seemed as seeking death.

Now a few words about adultery, a model for which is a square, including four people. Again, the situation may be specific. Lovers meet secretly, find explanations for their spouses, and lie to them and to their children. These and other factors add sensuality to their relations. E.g., Anděla, the heroine of one of novels, is a Czech woman married to an American, in her love to Jozef, who is also a Czech, she passes several stages: from blind passion to regret and disillusionment. No happy end. Perhaps an important factor of their love was common language, nationality, and culture. At the beginning of their relations they were very happy; they flew from the USA to Prague, where they spoke their native language. During their secret meetings they walked together holding hands, kissed in the street, smiled, laughed, and enjoyed every moment of being together:

\section{love + joy of being together}

(4) Ještě nikdy jsme se spolu neprocházeli, nanejvýš spěchali společně na letiště nebo se najist. ...Procházet se bylo sladké. Navíc v městě, kde jsme sa oba narodili. Josef mě držel křečovitě za ruku, jako kdyby se bál, že se mu mohu na pražské podvečerni ulici, plné stínů, ztratit. Uletět. Zmizet (Hercíková "Vášeň", p. 26). (Czech)

Never before we have walked together, we mainly hurried together to the airport or to have meals. ...To walk was so sweet. Moreover, in the city where both of us have been born. Josef held my hand tightly, as if he were afraid that I could be lost in the evening Prague streets, full of shadows. To fly away. To disappear.

When their love collapses, Anděla takes antidepressants which have no effect on her:

\section{unhappy love + disillusionment}

(5) Prášky neúčinkovaly, tř́štila jsem oči do tmy a bylo mi hưr a hůr̆, beznaděj se na mé valila jak lavina kamenü, jak hlína hrobu (Hercíková "Vášeň", p. 181). (Czech)

Pills did not work, my eyes stared into the darkness and I felt worse and worse, despair rolled on me like an avalanche of stones, as clay on the grave.

Analysis of all the samples of love display in Czech fiction gives an opportunity to describe them in the following ways (see Figure 7).

In literary texts I have found a lot of examples of direct description of love in combination with other feelings. But the skillfulness of the author is being displayed by the richness of his language, namely, means of stylistic syntax which we will discuss further on.

The results of my research show that in Czech prose, the means of stylistic syntax based on informational compression prevail and the rhetoric questions appear to be a powerful means of rendering psycho-emotional state of people who are in love. Before presenting illustrations of syntactic devices, I would like to make some comments. 


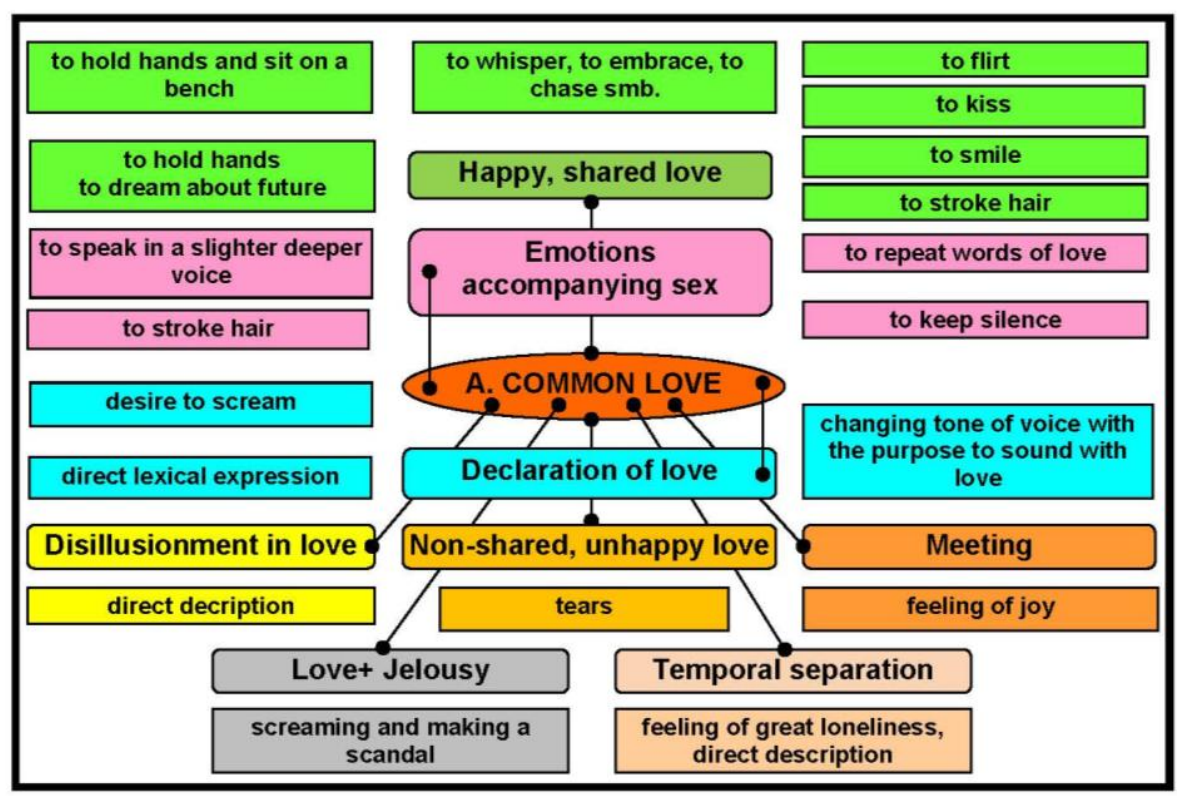

Figure 7: Display of common love in Czech fiction

As well as above all the Czech and Slovak examples are accompanied by translation, but the means of expressive syntax are underlined only in Slavic languages. The peculiarities of Czech and Slovak consist in the omission of the subject, free word order (unlike English), thus types and position of syntactic expressive means in a sentence are different. As far as it is impossible to give in details the content of the novel, in some cases some comments in brackets are added for better understanding of the context.

(6) The model oval - happy love - anaphora:

Hra se mi líbila. Přerosla mi přes hlavu. Přrerosla nám oběma přes hlavu.

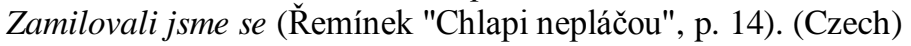

I liked the game. It grew over my head. It grew both of us over the head. We fell in love.

(7) The model triangle, non-shared, unhappy love - epiphora + anaphora + aposiopesis:

Zdálo se mi, že je mi sedmdesát pět let, že jsem stále $v$ té samé posteli a stále sama. Možná muž, se kterým bych byla schopna existovat, na světě není. Prostě $\underline{n e n i ́}$. Nebo žije $v$ Č́né. Nebo je už dávno ženatý a má tři děti. Nebo, nebo... (Nesvadbová "Bestiáŕ", p. 59). (Czech)

It seemed to me that I was seventy-five, that I was still in the same bed and all alone. Perhaps the man with whom I would be able to exist does not exist in the world. Simply doesn't. Or lives in China. Or has been married for a long time and has three children. Or, or... 
(8) Model square, adultery, love + jealosy - antithesis:

Byl tam s jinou. A já včera s jiným. Celé naše štěstí je vypưjčené, poslepované z ukradených chvil. Možna to ani neni štěstí, jen obyčejná nevěra, cizoložství, smilstvo a jaká hnusná slova pro to ještě existuji. Adultery (Hercíková "Vášeň", p. 48). (Czech)

He was there with another woman. And I was yesterday with another man. All our happiness is borrowed, a patchwork of stolen moments. Maybe this is not happiness, just an ordinary infidelity, adultery, fornication, and such ugly words for that exist. Adultery.

(9) love + regret, sadness - rhetoric questions + parallel constructions:

Zdrceně jsem se vrátila domů. Budu schopná ukázat Josefovi lahvičku s jeho parfémem? Co mi řekne? Že je Vưně milenců tím zázračným trikem, kterým se osvobodí od rodiny? Co se mnou bude? Ztratila jsem rodinu, ztratila jsem děti a ted' ztratím Jozefa (Hercíková "Vášeň", p. 179-180). (Czech)

In dismay I returned home. Will I be able to show Joseph a small bottle of his perfume? What will he say to me? That "The Smell of Lovers" (the name of the new perfume) is a miraculous trick which will make him free from his family? What will become of me? I've lost my family, I've lost my kids and I will lose Joseph.

Stylistic means of different levels are very important in expressing any modal meaning. In Figure $8 \mathrm{I}$ want to stress how important is their combinations in Czech literary texts, which reflect common love in general and its varieties: non-shared, unhappy vs. happy, shared. 


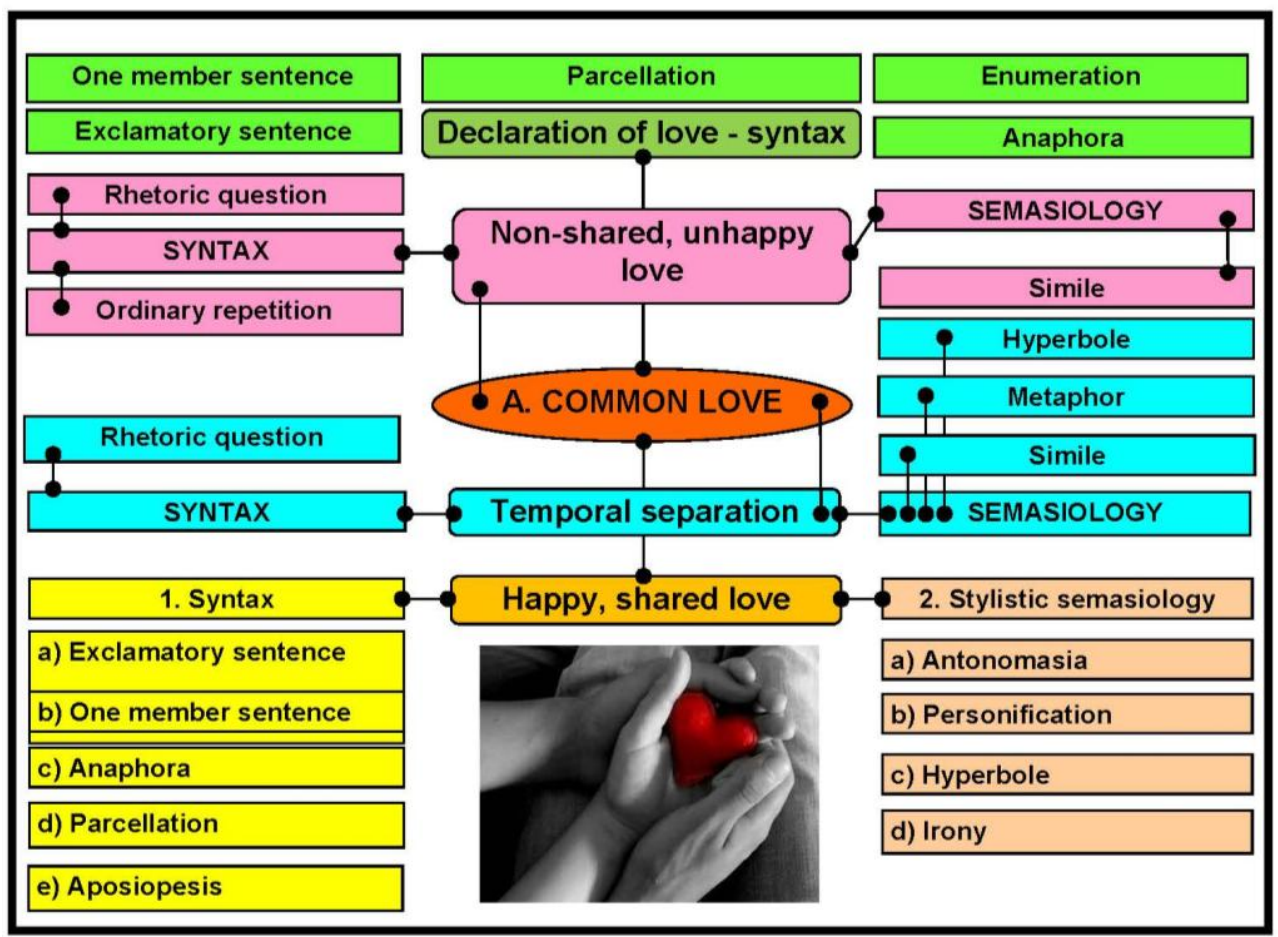

Figure 8: Stylistic means of Common love display in Czech literary texts

As far as I am interested in expressive syntax, below I present detailed data of its role in Czech fiction (see Table 1).

\begin{tabular}{|c|c|c|c|}
\hline \multicolumn{3}{|c|}{ 1. Syntactic stylistic means based on focusing } & 5 \\
\hline \multicolumn{2}{|l|}{ by pausation: parcellation } & 100 & \\
\hline \multicolumn{3}{|c|}{ 2. Syntactic stylistic means based on expansion: } & 27.6 \\
\hline \multicolumn{2}{|l|}{ a) repetitions } & 74.5 & \\
\hline ordinary & 6.45 & & \\
\hline anaphora & 48 & & \\
\hline epiphora & 6.45 & & \\
\hline anadiplosis & 16.25 & & \\
\hline framing & 16.25 & & \\
\hline parallel constructions & 16.25 & & \\
\hline Total & 100 & & \\
\hline \multicolumn{2}{|l|}{ b) expansions proper } & 25.5 & \\
\hline enumeration & 50 & & \\
\hline antithesis & 50 & & \\
\hline Total & 100 & & \\
\hline Total & & 100 & \\
\hline
\end{tabular}




\begin{tabular}{|l|l|l|l|}
\hline \multicolumn{3}{|l|}{ Syntactic stylistic means based on informational compression } & 61.7 \\
\hline $\begin{array}{l}\text { a) Syntactic stylistic means based on syntagmatic } \\
\text { compression of information }\end{array}$ & & \\
\hline aposiopesis & 12 & & \\
\hline nominative sentence & $\mathbf{3 5}$ & & \\
\hline one-member sentence & $\mathbf{4 5}$ & & \\
\hline antithesis & 8 & & \\
\hline Total & 100 & & \\
\hline $\begin{array}{l}\text { b) Syntactic stylistic means based on paradygmatic } \\
\text { compression of information }\end{array}$ & 32 & \\
\hline rhetoric questions & $\mathbf{1 0 0}$ & & \\
\hline \multicolumn{2}{|l}{} & 100 & \\
\hline 4. others (exclamatory sentences) & & 5.7 \\
\hline Total & & 100 \\
\hline
\end{tabular}

Table 1: Syntactic means of expressing emotion term LOVE in Czech fiction in \%

\section{Manifestation of love in Slovak fiction}

Discussing the ways of love manifestation in Slovak texts I will try to highlight differences of happy and unhappy love of people belonging to different social groups, of different age.

The model is an oval. The situation is as follows. A grown-up girl complains of her parents who are hanging on each other after many years of happy marriage, which makes her sad.

\section{happy, shared love}

(10) "Vy tomu nerozumiete, lebo ste to nezažili. Visia jeden na druhom. Ja som pre nich druhoradá. Tešia sa, ked’ sú spolu, mňa nepotrebujú. Také manželstvo som ešte nevidela. Iní sa po tolkých rokoch rozvádzajú, oni sa lúbia ako na začiatku..." (Gillerová "Láska si nevyberá", p. 48). (Slovak)

"You do not understand, because you have never experienced it. They are hanging on each other. I am of second-class to them. They rejoice being together, they do not need me. I have never seen such a marriage yet. Others divorce after so many years together, they love each other as at the beginning."

One of the critical problems in Slovakia is the woman's desire to work or to come back to work after the maternity leave (in details see Panasenko 2013). This situation is the keystone in the novel "Cukor a sol" ("Sugar and Salt") by Keleová-Vasilková. Everything is fine in Nora's family:

(11) Nora roky žila ako vo vatičke... obalená teplom, pohodlím a láskou (KeleováVasilková "Cukor a sol", p. 16). (Slovak)

Nora has been living for years like in a cotton ball (in diminituve form) ... wrapped in warmth, comfort and love. 
Her husband and she have two daughters, a large house, enough money, but Nora wants to come back to work, to earn her own money. This irritates her husband, their family collapses, but after many collisions the story has a happy end.

Now let us try to answer the question what makes love unhappy and how it ir reflected in our texts. We will start with the examples of unhappy love in fiction.

\section{unhappy love, disillusionment in love}

At the early days of their marriage, Tereza, the protagonist of the novel "Za to mi zaplatíš!" ("You will pay me for this!") by Nagyová-Džerengová, got up early, prepared breakfast for her husband and they were sitting in silence. She followed his movements with loving sight. But then she realized that he kept silence because found her silly and not equal to him - he was a doctor and she was only a nurse without higher education. Tereza is tired of her husband's jealousy and scorn and leaves him.

Irma, another character in this book, is crazy about order in her flat; she polishes the floor, kitchen utensils, but forgets to cook something and to take care of her husband. As far as she can't forgive her husband's betrayal, she does not sleep well, she smokes too much, takes alcohol, threatens and curses him, and hides their daughter from him. Her love turns into hatred. They divorce and her former husband marries another woman (Nagyová-Džerengová "Za to mi zaplatíš!").

There were usually many children in a Slovak family (Panasenko 2013). Though their number is not very large nowadays, men do want to have heirs, and a women's refusal to bear children leads to a divorce or separation (Lukáš and his mistress Renáta in a book "Vôňa karameliek" - "The smell of caramel" by Hamzová):

(12) Poznal ju až príliš dobre. Ona si to o ňom zrejme myslela tiež. Bola krásna, takmer dokonalá. Jej telo mohlo sútažit's európskymi modelkami. Dokonalé miery, dokonalé pohyby, dokonalý úmysel... dokonalý chlad. Toto telo ho už dávno nevzrušovalo. Bolo síce krásne, ale studené ako l’ad. Príliš dokonalé na to, aby sa nechalo dobrovolne zničit'. Napriklad tehotenstvom. Presne tak ako kedysi Silvia. Ani Renáta nikdy nechcela mat' deti (Hámzova "Vôňa karameliek", p. 103). (Slovak)

He knew her too well. She probably also thought about him. She was beautiful, almost perfect. Her body could compete with European models. Perfect sizes, perfect movements, perfect intention ... perfect chill. This body has not inspired him with passion any more. Although it was beautiful, it was as cold as ice. Too perfect to be voluntarily destroyed. For example, by pregnancy. Just as once Silvia did. Renáta never wanted to have children.

In these three cases we may state that the reason of unhappy love and marriage lies in the characters' mistakes in their behaviour. There are only two people involved (the model oval), but the family is on the verge of wreck.

In other books, examples from which are not included into our sources for this article, I have come across other cases of unhappy love / marriage: alcoholism, sponging, vagrancy, different religion communities, creation of image, an ideal which is very difficult to find in real life and love to it, etc., but these cases will be considered in further publications.

Some examples with the model triangle. 
non-shared, unhappy love

(13) Dominika, a teenager, is very thin, lost her appetite:

Bola pravda, že som v poslednom čase schudla. Vôbec mi nechutilo, citila som ako v mrákotách. Zadúšala som v sebe zúfalú lásku, zúfalú túžbu po niekom, kto mi nikdy nebude patrit'. A nevedela som, čo s tým dělat' (Gillerová "Láska si nevyberá", p. 54). (Slovak)

It was true that recently I have lost weight. Nothing attracted me, I felt like in darkness. I was strangling in myself desperate love, desperate desire for someone who will never belong to me. And I did not know what to do with this.

\subsection{Syntactic expressive means of love manifestation in Slovak fiction}

Having analyzed prosaic texts from stylistic point of view, we may speak about the following combinations of them in different models:

(1) the model oval - happy love: aposiopesis, exclamatory sentences, rhetoric questions, nominative sentences, enumeration; declaration of love: aposiopesis, enumeration, anaphora, nominative sentences, exclamatory sentences, rhetoric questions, parcellation; temporal separation and meeting: interrogative exclamatory sentences, aposiopesis, exclamatory sentences; love + fear to lose the partner: exclamatory sentences, aposiopesis, interrogative exclamatory sentences, parallel constructions (complete and partial), framing;

(2) the model triangle - non-shared, unhappy love, disillusionment in love: aposiopesis, enumeration, antithesis, parcellation; non-shared, unhappy love, disillusionment in love + jelousy: exclamatory sentence, interrogativeexclamatory sentences, aposiopesis, rhetoric questions, epiphora;

(3) the model square, adultery - non-shared, unhappy love, disillusionment in love + hatred + jelousy: exclamatory sentences, rhetoric questions.

Let us illustrate these three models with some examples. The model oval - happy love rhetoric questions:

(14) Je to naozaj láska? Alebo len očarene? (Keleová-Vasilková "Cukor a sol', p. 123). (Slovak)

Is it really love? Or just enchantment?

(15) exclamatory sentence, nominative sentence:

ON! (Gillerova "Záhada zadnej izby", p. 14). (Slovak) HE!

(16) one-member sentence:

"Lúbim t’a. Vieš o tom?" ... "Aj ja teba. Velmi.." (Keleová-Vasilková "Cukor a sol", p. 182). (Slovak)

"I love you. Do you know about it?"..."I love you, too. Much."

(17) love + fear to lose the partner - aposiopesis + interrogative exclamatory sentence:

Vd'aka nemu mala prestižne postavenie vo firme, dobrý plat, všade ho sprevádzala, kamarátky jej závideli pekného a úspešného muža, ktorý rešpektoval jej nezávislost' a slobodu... a teraz by ho mala stratit??! (Hámzova "Vôňa karameliek", p. 102) (Slovak) 
Thanks to him, she had a prestigious position in the company, good salary, accompanying him everywhere, her friends envied her handsome and successful man who respected her independence and freedom ... and now she should lose him?

(18) framing + exclamatory sentence:

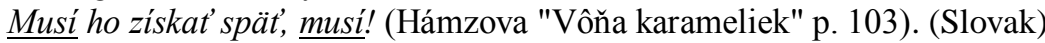

She must get him back, she must!

Model triangle - non-shared, unhappy love, disillusionment in love:

(19) parcellation:

Zrejme sa t’ažko zmieruješ s tým, že Deniska už patrí do iných sfér. Tých dospeláckych. A chýba ti (Gillerová "Láska si nevyberá", p. 87). (Slovak)

Obviously, it is difficult for you to accept the fact that Deniska (diminutive/familiar name of Denisa) already belongs to other spheres. To the adults. And (you are) missing her.

Model square, adultery - non-shared, unhappy love, disillusionment in love + jelousy + hatred:

(20) rhetoric questions:

Objíma teraz tú Milku? Takisto ako mn̆a? Lúbi ju rovnako? (Keleová-Vasilková "Cukor a sol", p. 142). (Slovak)

Is he hugging Milka (diminutive/familiar name of Ludmila or Emília) now? In the same way like me? Does he love her like me?

(21) antithesis:

Postupne zistovala, že láska a priatel'stvo, ktoré $k$ Lubošovi celé roky citila, sa mení na tichú, vždy pritomnú a spal'ujúcu nenávist' (Keleová-Vasilková "Cukor a sol", p. 7). (Slovak)

Step by step, she was considering that love and friendship, which she felt to Luboš for many years, has been changing to silent, always present and burning hate.

Linguistic and extralinguistic means of expressing emotion term love in Slovak are reflected in figure 9 . 


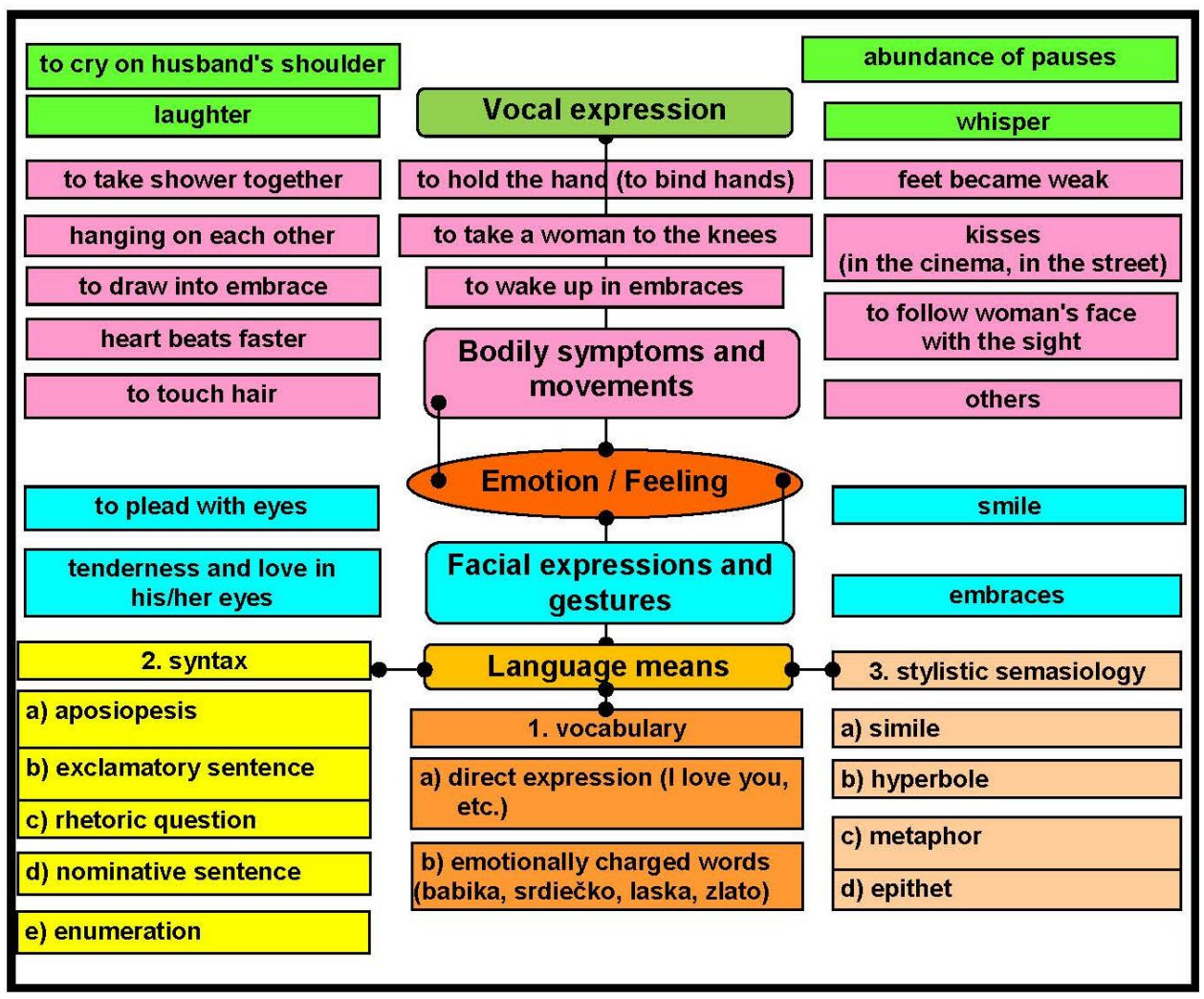

Figure 9: Linguistic and extralinguistic means of expressing feelings and emotions in Slovak fiction

Frequency of different stylistic means is presented in Table 2. We see that means based on syntagmatic compression of information prevail as well as exclamatory sentences.

\begin{tabular}{|l|l|l|l|}
\hline \multicolumn{2}{|l|}{ Syntactic stylistic means based on focusing } & 2 \\
\hline by pausation: & 70 & & \\
\hline parcellation & 30 & & \\
\hline detachment & 100 & & \\
\hline Total & & 29 & \\
\hline 2. Syntactic stylistic means based on expansion: & & \\
\hline a) repetitions & 20 & & \\
\hline ordinary & 20 & & \\
\hline anaphora & 20 & & \\
\hline epiphora & 20 & & \\
\hline framing & 20 & & \\
\hline parallel constructions & 100 & & \\
\hline Total & &
\end{tabular}




\begin{tabular}{|c|c|c|c|}
\hline \multicolumn{2}{|l|}{ b) expansions proper } & \multirow[t]{2}{*}{71} & \\
\hline enumeration & 75 & & \\
\hline antithesis & 25 & & \\
\hline Total & 100 & & \\
\hline Total & & 100 & \\
\hline \multicolumn{3}{|c|}{ 3. Syntactic stylistic means based on informational compression } & 65 \\
\hline \multicolumn{2}{|c|}{$\begin{array}{l}\text { a) Syntactic stylistic means based on syntagmatic } \\
\text { compression of information }\end{array}$} & 94 & \\
\hline aposiopesis & 76 & & \\
\hline nominative sentence & 4 & & \\
\hline one-member sentence & 4 & & \\
\hline antithesis & 16 & & \\
\hline Total & 100 & & \\
\hline \multicolumn{2}{|c|}{$\begin{array}{l}\text { b) Syntactic stylistic means based on paradygmatic } \\
\text { compression of information }\end{array}$} & 16 & \\
\hline rhetoric questions & 100 & & \\
\hline Total & & 100 & \\
\hline \multicolumn{2}{|l|}{ 4. others } & 40 & 23 \\
\hline exclamatory sentences & $\mathbf{7 0}$ & & \\
\hline interrogative exclamatory sentences & 30 & & \\
\hline Total & 100 & & \\
\hline \multicolumn{2}{|l|}{ Total } & & 100 \\
\hline
\end{tabular}

Table 2: Syntactic means of expressing emotion term LOVE in Slovak fiction in \%

\section{Discussion and conclusions}

I have made only the first step in the direction of contrastive analysis of emotional concepts of different cultures: Czech and Slovak. The results obtained from literary texts analysis show that there are some differences in the ways of perceiving love, its understanding, evaluation in relation to a partner, etc.

Of all stylistic ways of expressing emotion term LOVE syntactic ones prevail, namely in Czech fiction these are stylistic means based on informational compression $(61.7 \%)$ and based on expansion of information (27.7 \%). In Slovak fiction, stylistic means based on informational compression prevail $(65 \%)$ as well as exclamatory sentences $(23 \%)$.

Syntactic means are connected with different types of model relations, which we name oval, triangle and square according to the number of participants involved into the situation (two, three and four correspondently). In Czech prose rhetoric questions rank one, followed by one member sentences, nominative sentences, anaphora and exclamatory sentences. In Slovak texts the list of top five starts with aposiopesis, followed by exclamatory sentences, one member sentence, interrogative exclamatory sentences and enumeration. What does it mean? How is it connected with cultural identity? Each device has its own function in the literary text. Rhetoric questions need no answer; they accompany doubt, regret, and disillusionment. They also need no 
interlocutor, are typical of inner monologue. Exclamatory sentences as well as interrogative exclamatory ones, on the contrary, imply the addressee. They are also connected with intonational component of speech: level of loudness, peculiar melodic contour, emphatic word stress. All these factors testify to the high emotionality of the speaker, whereas rhetoric questions imply solitude and silence. One member sentences, nominative sentences are connected with laconic brevity, and self-restraint. Aposiopesis, a sudden break in speech, has another function - to express great emotional tension, stress, and unwillingness to speak; it is used to render the speech of a person who cannot find words to express one's feelings. Thus, the analysis of linguistic, namely stylistic syntactic means, shows considerable differences between their representation in Czech and Slovak prose.

Extralinguistic ways of expressing happy love are: Czech fiction: bodily symptoms and movements (to kiss, to hold hands) and facial expression (to smile); Slovak fiction: bodily symptoms and movements (kisses, to draw into embrace, to hold the hand /to bind hands; felt her or his heartbeat getting faster), facial expressions (laughter, smile), vocal expression (whisper), etc.

Our next step will be contrastive analysis of other emotion terms in languages with different structure.

\section{References}

Components of Emotional Meaning. A Sourcebook (2013). Fontaine, Johnny, Scherer, Klaus R., Soriano, Cristina (eds.). Oxford, Oxford University Press, UK.

Frijda, Nico H. (1986). The Emotions. Cambridge University Press, Cambridge, UK.

Kyseliuk, N.P. (2007). "Syntactic means of expressing emotion "joy" (in modern English"). Language and culture, iss. 9, vol. VI (94), 146-150 [in Russian].

Likhareva, Irina (1982). Interrelations of prosodic, lexical and lexico-grammatical means of expressing modal meanings in English (based on phrases expressing certainty and doubt. Synopsis for PhD thesis. Moscow [in Russian].

Nakonečný, Milan (2000). Lidské emoce. Academia Praha, Czech Republic. [in Czech].

Nikonova, Vera (2008). Conceptual space of the tragic in the plays by Shakespeare: cognitive-poetic analysis. Synopsis for thesis of the DrSc. dissertation. Kiev National Linguistic University [in Russian].

Ortoni, Andrew, Clore, Gerald L., Collins, Allan (1988). The Cognitive Structure of Emotions. Cambridge University Press, Cambridge, UK.

Panasenko, Nataliya (2013). "Czech and Slovak family patterns and family values in historical, social and cultural context". Journal of Comparative Family Studies. Alberta: Un-ty of Calgary. Vol. XXXIV, No 1, January-February, 79-98.

Panasenko, Nataliya I. (2009). "Linguistic and extralinguistic means of expressing feelings and emotions in languages with different structures". Studia Germanica et Romanica. Scholarly papers of Donetsk National Un-ty, iss. 6, No 1, 89-108 [in Russian].

Panasenko, Nataliya (2012). "Linguistic markers of emotional concept Love in literary texts". US-China Foreign Language. April, vol. 10, No. 4, 1067-1084. 
Panasenko, Nataliya, Démuthová, Slavka, Ručková, Gabriela, Varečková, L'ubica (2012). "Cross-cultural study of love evaluation and display by Slovaks and Czechs". Humanities across the Borders: [collection of papers / editors-in-chief O.L. Byessonova, N.I. Panasenko]. Donetsk-Trnava: DonNU, , 253-282.

Panasenko, Nataliya I., Krivonovska, Larisa L. (1983). "Intonational and grammatical means of expressing modal meanings of assurance/ uncertainty in direct speech". Foreign Philology, № 72, Lviv, 56-64 [in Ukrainian].

Panasenko, Nataliya, Trnka, Andrej, Petranová, Dana, Magál, Slavomír (2013). "Bilingual analysis of LOVE and HATRED emotional markers (SPSS-based approach)". Proceedings of the 3rd Workshop on Sentiment Analysis where AI meets Psychology (SAAIP 2013), IJCNLP 2013, Nagoya, Japan, October 14, 15-23.

Rozhkova, Galina I. (1974). Perception of Emotional Intonations. A Thesis for the Scholarly Degree of Candidate of Psychology. Moscow. [in Russian].

\section{Sources of illustration material}

\section{Czech}

Hercíková, Iva (2002). Jsem nebe. Jizda šikmo svahem. Praha: Motto. Hercíková, Iva (2003). Vášeň. Praha: Motto.

Hornová, Lenka (2006). Zdena Čistá: Můj život s Králem. Praha: Nakladatelství XYZ.

Lanczová, Lenka (2010). Manželky, milenky, zoufalky. Česky Těšín: Vydavatelství Víkend.

Lanczová, Lenka (2010). Milenky a hřišnici. Česky Těšín: Vydavatelství Víkend.

Nesvadbová, Barbara (1999). Bestiářr. Praha: Motto.

Řemínek, Jozef. (2000) Chlapi nepláčou aneb. Kladno, to je město Praha: Nakladatelství Otakar II.

Viewegh, Michal (2008). Povidky o manzelstvi a o sexu. Brno: Nakladatelství Petrov.

Viewegh, Michal (1997). Výchova dívek v Čechách. Brno: Nakladatelství Petrov.

\section{Slovak}

Fulmeková, Denisa (2007). Dve čiarky nádeje. Bratislava: Ikar.

Gillerová, Katarína (2004). Laska si nevybera. Bratislava: Slovenský spisovatel'.

Gillerová, Katarína (2008). Zahada zadnej izby. Bratislava: Slovenský spisovatel'.

Hamzová, Mária (2005). Láska s nami zatočí. Bratislava: Vydavatel'stvo Motýl'.

Hamzová, Mária (2007). Šepkanie osudu. Bratislava: Vydavatel'stvo Motýl'.

Hamzová, Mária (2005). Vôña karameliek Bratislava: Vydavatel'stvo Motýl'.

Keleová-Vasilková, Táňa (2004). Cukor a sol. Bratislava: Ikar.

Nagyová-Džerengová, Petra (2006). Za to mi zaplatíšs! Bratislava: Ikar. 